\title{
UNDERGRADUATE STUDENTS' PERCEPTIONS AND ATTITUDES TOWARDS A CAREER IN TOURISM INDUSTRY: THE CASE OF INDONESIA
}

\author{
Muhammad Iqbal Rosyidi \\ Directorate of Strategic Research \\ Ministry of Tourism and Creative Economy Indonesia \\ 17 Medan Merdeka Selatan Street, Central Jakarta, 10110, Indonesia \\ Email: iqbalrosyidi@kemenparekraf.go.id
}

\begin{abstract}
As a world-class tourism destination, Indonesia is facing challenges in providing competent tourism human capital. Currently, the majority of tourism labor in Indonesia are low levels of education, and only a few of them are graduated from higher education. Empirically, numerous studies suggest that many graduates from various tourism schools in several countries preferred to not opt for tourism careers. This study aimed to discover and analyze the perceptions and attitudes of final year students majoring in tourism and hospitality in Indonesia to pursue a career in the tourism industry. Using an online distributed questionnaire through snowball sampling method, this study obtained 422 completed responses of tourism and hospitality undergraduates from Jakarta, Bandung, Lombok, Makassar, Palembang, Bali, Yogyakarta, Surakarta, and Batam. The collected data then analyzed by perception-importance analysis using cartesian diagram and cross-tabulation analysis. This study found that career advancement and salaries were considered important factors but got a bad perception. However, the nature of the tourism industry's work that offers an enjoyable and fun environment is essential and earned a positive perception. This study also presents some implications, mainly for the tourism industry in Indonesia.
\end{abstract}

Keywords: Undergraduate students, tourism industry, perceptions, attitudes.

\section{Introduction}

Tourism human capital is an essential attribute for the tourism industry. The empirical studies in Jakarta suggest that human capital is the most significant factor for tourist destination competitiveness (Budi, 2015). Those human capital or tourism labors are the front liners who provide services to consumers and play an important role to deliver experiences for travelers (Solnet \& Hood, 2008). The nature of work and basic functions of the tourism industry require them to interact with tourists directly and play a substantial responsibility in conveying tourist satisfaction.

The development of the tourism business like in developing countries increases the needs of professional as well as skilled labor (Liu \& Wall, 2006). Typically, tertiary education, whether delivered through vocational or academic programs, is the central producing institution for tourism workforce (Le, Klieve, and McDonald, 2018). However, this is not the case in Indonesia. According to a report from the Central Statistics Agency, in 2019, most of the tourism labor (57.3\%) attained low levels of education (elementary and junior high schools) (Bachrun, 2020). The number of tourism workers who complete higher education (diploma and undergraduate programs) was only $7.07 \%$. Therefore, in Indonesia, the current number of tourism labor who graduated from higher education is still scarce.

Tourism human capital is an essential attribute for the tourism industry. The empirical studies in Ja-karta suggest that human capital is the most significant factor for tourist destination competitiveness (Budi, 2015). Those human capital or tourism labors are the front liners who provide services to consumers and play an important role to deliver experiences for travelers (Solnet \& Hood, 2008). The nature of work and basic functions of the tourism industry require them to interact with tourists directly and play a substantial responsibility in conveying tourist satisfaction.

The development of the tourism business like in developing countries increases the needs of profesional as well as skilled labor (Liu \& Wall, 2006). Typically, tertiary education, whether delivered through vocational or academic programs, is the central producing institution for tourism workforce (Le, Klieve, and McDonald, 2018). However, this is not the case in Indonesia. According to a report from the Central Statistics Agency, in 2019, most of the tourism labor (57.3\%) attained low levels of education (elementary and junior high schools) (Bachrun, 2020). The number of tourism workers who complete higher education (diploma and 
undergraduate programs) was only $7.07 \%$. Therefore, in Indonesia, the current number of tourism labor who graduated from higher education is still scarce.

Previous studies suggest that many graduates from tourism institutions chose to leave tourism careers (Ahmad, Rashid, \& Shariff, 2014; AlBattat \& Som, 2013) or even failed to enter the tourism-related industry. This phenomenon happens due to the perception of low satisfaction of profession, poor work environment and wage, and the turnover amongst staff that are too frequent (Anandhwanlert \& Wattanasan, 2017; Sibanyoni, Kleynhans \& Vibetti, 2015; AlBattat, Som, \& Helalat, 2014).

The demand of competent and high educated tourism labor also encounters other obstacles, like candidates coming from non-tourism backgrounds. This phenomenon happens due to the tourism industry's image as an "escape plan" by those who do not have qualified skills in other sectors (Brien, 2004). Conse-quently, the tourism sector is often inadequate to fit hu-man capitals' best supply within the nation. Meanwhile, the inadequate and unqualified human capital leads to the poor image of tourism industry (Pitso, 2018). This dilemma is a challenge for tourism policymakers in guaranteeing candidates' appropriateness with the required level, especially for preparing Indonesia to compete at the international stage and achieve the targeted aspirations.

Concurrently, the Covid-19 pandemic brings a large-scale impact on the tourism sector worldwide (Škare, Soriano, \& Porada-Rochoń, 2020; UNWTO, 2020) Indonesia has felt the shock as a consequence of limitation of people's mobility inter continents and within the country. It encourages tourism business leaders to restructuring resources by decluttering laborers (Dinarto, Wanto, \& Sebastian, 2020). Furthermore, this pandemic has unfortunately caused the tourism labors to lose income and hence leave the jobs (Hakim, 2020).

As a consequence, jobs will be challenging to grasped by vacancy hunters, including the newly graduated tourism students. This condition raises concerns for the prospective workers in choosing a career. The tourism fresh-graduates have to endure tough competition for their first job, yet they also have to compete with workers who have previously worked but got layoffs due to pandemics. Sad but true, the candidates also have to bear the risk of being contracted to Covid-19 since direct contact with tourists is inevitable in the tourism sector. Besides, a pay cut and employment ter-mination during the pandemic has alarmed the newly graduates that the tourism industry is unstable and often hit by a shock.
Several investigations in many countries have been conducted to identify attitudes, perceptions, and students' desires for a career in the tourism industry. Those studies discussed jobs' preferences and the role of individual characteristics such as age, gender, and work experience in influencing students' perceptions and attitudes (Kusluvan \& Kusluvan, 2000; Richardson, 2009; Richardson \& Butler, 2012; Wen, Li, \& Kwon, 2019).

Although some explorations concerning students' attitudes and perceptions for careers in the tour-ism industry have been carried out in several countries, a comparable study has not yet been conducted in Indonesia. As a developing country and an attractive tourist destination in the Asia Pacific, arguably, prospective Indonesian tourism labors' characteristics and preferences cannot be compared to those in developed countries. Therefore, this study raises several questions including how tourism students perceive jobs in the tourism industry? what are the attitudes of tourism students for a career in the tourism industry post pandemic Covid-19? What are the business fields and work locations in the tourism industry preferred by the students?

\section{Factors Affecting Career Choice}

Generally speaking, a person's career choice is determined by psychological and sociological aspects (Brown, 2002). Psychological aspects referred to internal factors, are associated with individual factors: personality and ability to do a job. Psychological factors are related to how a person is treated as a child, and the sociological one is measured by how someone perceives something. According to Johnson and Mortimer (as cited in Brown, 2002), sociological aspects were influenced by demographic and environmental factors or external factors. In this case, demographic factors can be in ethnicity, social status, education, and gender. Meanwhile, environmental factors can be in the form of social influence, work environment, and the econo-mic environment.

A single comprehensive theory regarding a person's career choice was developed by Lent $e t$ al. (as cited in Brown, 2002), known as Social Cognitive Career Theory (SCCT). SCCT emphasizes three main va-riables: self-efficacy, expectations regarding results, and personal goals. Self-efficacy shows an individual's belief in their abilities, and expectations regarding results speak about an individual's belief in the consequences of performing certain behaviors. Meanwhile, personal goals are a determination to engage in certain activities or to influence specific future 
outcomes. In SCCT theory, these three variables interact with individual conditions (gender, ethnicity, abilities, and personality) and contextual factors (family, culture, familiarization of gender roles) in shaping the direction of one's career development.

Although internal factors shape one's career path, sociological views also observe the environment as something that considerably affects one's career decision. As mentioned earlier, the power from the environment can be in the form of social influence, actors who influence a person, and environmental conditions such as economic conditions, the labor market, and the unemployment rate (White, 2007). Apart from it, other parties who can influence one's career choice were industry mentors and friends (Brown, 2002; Lee, Lee, \& Dopson, 2019).

\section{Characteristics of Jobs in the Tourism Industry}

The workers' characteristics in the tourism industry are often unique compared to other sectors. It is easy to find non-standard workers in the tourism industry, such as independent/freelance workers and workers with contracts or casual workers. Formally, workers in the tourism industry are required to have high interpersonal skills to deal with tourists. The ability to control oneself emotionally whilst facing complaints is called emotional labor (Chan, 2017).

In most cases, workers in the tourism industry must have particular skills, such as chefs who must master gastronomy and food processing management. Similarly, museum curators must know a lot about history, and dive tour guides must have diving skills. However, jobs in the tourism industry also often require non-specific skills and tend to be easy for some people, such as restaurant waiters, cashier/ticket officers, and hotel concierge/porters.

Another characteristic of employment in the tourism industry is student interns' involvement in the field and directly dealing with tourist. Students consider that internship programs are beneficial for improving skills and work experience even though they must be willing not to collect remuneration. Unfortunately, apprentice students are usually not fully experienced, so that the expected outcomes are not achieved. As a result, negative perceptions of employment in the tour-ism industry have long surged.

Unlike other industries that produce tangible materials like cars, shoes, or furniture, the tourism industry provides intangible products such as experiences for visitors. As a result, customer satisfaction solely depends on the experience given and how it is delivered by staff. Workers in the tourism industry have a considerable function in managing the tourism industry's sustainability because they have to ensure customer satisfaction by directly dealing with tourists (Baum, 2016).

\section{Attitudes and Perceptions of Students towards Careers in the Tourism Industry}

On a broad scale, studying and evaluating students' attitudes towards the tourism industry careers is vital to predicting and planning tourism labor within the country or tourist destinations. Their attitudes are influenced by several factors, such as personal reasons, the nature of the jobs, human factors, educational factors, and individual characteristics (Jiang \& Tribe, 2009). Meanwhile, Le et al. (2018) added that interaction with tourists and pre-apprenticeship education also affected individual attitudes in choosing a career in the tourism industry. According to Wan Yim King and Kong Weng Hang (2011), students who had positive attitudes and perceptions of a specific industry tend to be more likely to join the concerned industry after graduation.

Tourism students often get an overview of how a tourism business is operated and the characteristics of jobs in the tourism industry whilst schooling. They got a rational representation directly after going through practical work/apprenticeship or doing a part-time job (Dewar, Sayers, \& Meyer, 2002). Prospective workers will usually evaluate the characteristics of the job. One of their evaluations is related to assessing whether the industry can meet their expectations and employment judgments.

Based on the evaluation results, it is common for tourism students to leave the tourism industry after graduation (Cassel, Thulemark, \& Duncan, 2018). Some people usually perceive jobs in the tourism industry as a 'stepping stone' before getting the job they dream of (Dewar et al., 2002). Fortunately, a positive attitude accompanied by a desire to continue a career in the tourism industry is an excellent precondition so that a country could have great quality and competitive tourism sectors (Kusluvan \& Kusluvan, 2000).

Based on the existing literature, students' perceptions of working in the tourism industry tend to be negative. This situation implies a decline of interest in tourism careers. Several students' negative perceptions are related to low salaries and benefits (Lacher \& Oh, 2012), limited promotion opportunities (Wen et al., 2019), and relatively high employee turnover (AlBattat et al., 2014). Also, Kusluvan and Kusluvan (2000) stated that students believed the tourism industry was a stressful profession, gave low status in society, and was not a permanent job. 
Nevertheless, several positive perceptions of students were found. Wang and Huang (2014) showed that students valued the tourism industry positively. They believed the tourism industry could allow them to communicate with foreign tourists and have a close bond with diverse cultures. Wijesundara (2015) said that the shift work in the tourism industry received positive responses from students.

\section{Desire for Careers in the Tourism Industry}

Kusluvan and Kusluvan (2000) defined nine variables as factors influencing students' desire for tourism industry careers. The nine factors including nature of work, social status, industry-person congeniality, physical working conditions, pay/benefit, promotion opportunities, coworkers, managers, and commitment to work in the tourism industry are correlated and influenced with students' career choice in the tourism industry. Several recent studies still use all the variables above (Le et al., 2018; Tuzunkan, 2018; Wen et al., 2019), while other studies only partially use those variables (Adhoch, 2019; El-Dief \& El-Dief, 2019; Mohammed, 2018). Previous research regarding student's attitudes, perceptions, and desire for a career in the tourism industry is presented in Table 1.

\section{Research Method}

Considering that respondents' perceptions and attitudes are beyond the researcher's control and can be measured universally and objectively, this research was conducted with a positivistic paradigm. This study relies on empirical knowledge of students' perceptions and attitudes for a career in the tourism industry through a positivistic approach. The approach's core is to experiment with phenomena that need to be intentionally observed using a series of procedures.

Quantitative research methods are still considered relevant to satisfy various questions in this study. Most of the previous research was using quantitative methods (Amissah et al., 2020; El-Dief \& El-Dief, 2019; Ibrahim, Saber, Mustapha, Othman, \& Salim, 2020; Tuzunkan, 2018), although there were also researchers who used qualitative methods (Chan, 2019) or even mixed-method ( $\mathrm{Vu}, 2020$; Wen et al., 2019). The use of quantitative methods in this research sees Kusluvan and Kusluvan (2000) as a model, who has become the pioneers in this topic. Several studies in 2015 with quantitative and mixed-method involving 100 to 614 respondents have been conducted (Ibrahim et al., 2020; Wen et al., 2019). The selection of respondents often involved a single tourism university/ polytechnic. However, some researchers also involved various universities/polytechnics.
Table 1

Previous Studies Regarding Students' Perceptions and Attitudes towards a Career in Tourism Industry

\begin{tabular}{ll}
\hline \multicolumn{1}{c}{$\begin{array}{c}\text { Researchers / } \\
\text { Country }\end{array}$} & \multicolumn{1}{c}{ Findings } \\
\hline Kusluvan and & Factors that influence negative attitudes \\
Kusluvan (2000) / & towards careers in tourism are: \\
Turkey & - stressful workload \\
& - long working hours \\
& - tiring and seasonal (unstable) work \\
& - low social status \\
& - disappointing promotions \\
& - low wages and small incentives \\
& - unqualified managers \\
& - poor managerial attitudes and \\
& behaviour towards employees \\
- & unqualified co-workers \\
- & poor co-worker attitudes and \\
& behaviour \\
- & poor physical working conditions
\end{tabular}

Richardson (2009)/ Tourism and hospitality students did not Australia believe that the tourism industry could offer the qualities they considered necessary in choosing a future career.

Bamford (2012) / Students believed that the tourism New Zealand industry provides low wages, fair work environment, requires long working hours, good co-workers, and does not require certain degrees.

Richardson and Tourism students did not consider the Butler (2012) / tourism industry as an attractive career Malaysia path.

Wen et al. (2019) / Students had positive attitudes towards Mainland China pursuing a career in the hotel industry. Factors, such as compensation, benefits, and promotion opportunities, significantly impacted their intentions, meaning that they still wanted to work in the hospitality industry after graduation.

Amissah, Mensah, Students counted that careers in the Mensah, and hospitality and tourism industry could Gamor (2020) / allow them to take care of others, build Ghana their private businesses, gain transferable skills, and have the opportunity to pursue higher education/training.

This study involved 422 undergraduate students from several university and polytechnic in Indonesia. Selected participants came from universities that collaborated in the past work with the Ministry of Tourism and Creative Economy. However, the total respondents in this study represent a margin of error of $4,72 \%$ with a $95 \%$ confidence level. 
The data were distributed and collected using online questionnaires using SurveyMonkey platform. Data collection using online platforms have also been carried out in several previous studies (Ibrahim et al., 2020; Wen et al., 2019) like Survey Monkey (Bamford, 2012) or email (Le et al., 2018). Given the current situation that does not make it possible to conduct a face-to-face encounter, the online questionnaire method is considered adequate and efficient for respondents labelled as $\mathrm{Z}$ generations who are technology and internet savvy. The link of questionnaires was distributed via WhatsApp Messenger, forwarded to colleagues and lecturers at the 13 tourism educational institutions listed in Table 2. The distribution of questionnaires carried on April, 20 to May, 292020. Messages were then forwarded to students who met the criteria. The data were collected by using the snowball sampling method.

The questionnaire consists of four parts. Before entering the first part, there are introductory and screening questions to ensure that respondents meet the stan-dards. The first part of the questionnaire asks the res-pondents' profile, consisting of gender, education level, experience in a tourism vocational high school, work experience in the tourism industry, and industry in-ternship experience. The second part explores the fac-tors considered necessary for tourism students and their perceptions of those factors. The third section explores students' desire for a career in the tourism industry before and after the Covid-19 pandemic. If a respondent does not want to pursue a career in the tourism industry, the questionnaire will reach its end.

Table 2

List of Respondents' University, Polytechnic, or College

\begin{tabular}{ll}
\hline University/Polytechnic/College & \multicolumn{1}{c}{ City/Province } \\
\hline Medan Tourism Polytechnic & Medan, North Sumatra \\
Palembang Tourism Polytechnic & $\begin{array}{l}\text { Palembang } \\
\text { Bali Tourism Polytechnic }\end{array}$ \\
Makassar Tourism Polytechnic & $\begin{array}{l}\text { Makassar, South } \\
\text { Sulawesi }\end{array}$ \\
Lombok Tourism Polytechnic & $\begin{array}{c}\text { Praya, West Nusa } \\
\text { Tenggara }\end{array}$ \\
Bandung Institute of Tourism & Bandung, West Java \\
Bunda Mulia University & Jakarta \\
Trisakti College of Tourism & Jakarta \\
Sahid College of Tourism & Jakarta \\
Batam Tourism Polytechnic & Batam, Riau \\
& Archipelago \\
Ambarukmo College of & Yogyakarta \\
Tourism & Bandung, West Java \\
Yapari College of Tourism & \\
Economy & Surakarta, Central Java \\
\hline Sebelas Maret University &
\end{tabular}

On the other hand, if the respondent is either in doubt or wants a career in the tourism industry, they must proceed to the section about students' preferences towards business fields and locations for tourism careers. However, before the questionnaire was widely distributed, the filling trial was carried out involving 30 tourism students.

This study measures five over nine variables used by Kusluvan and Kusluvan (2000) with the fol-lowing questions:

\section{Table 3}

Variables and Indicators Applied

\begin{tabular}{|c|c|c|}
\hline Variables & Indicators & Code \\
\hline \multirow[t]{7}{*}{ Nature of work } & Fun/enjoyable work & $\mathrm{J} 1$ \\
\hline & Fun work environment & $\mathrm{J} 2$ \\
\hline & Friendly co-workers & $\mathrm{J} 3$ \\
\hline & $\begin{array}{l}\text { Standard working hours ( } 40 \\
\text { hours per week) }\end{array}$ & $\mathrm{J} 4$ \\
\hline & Permanent job & $\mathrm{J} 5$ \\
\hline & $\begin{array}{l}\text { A job that allows freedom of } \\
\text { work (work independently) }\end{array}$ & $\mathrm{J} 6$ \\
\hline & $\begin{array}{l}\text { High-risk job (threatens } \\
\text { personal safety and health) }\end{array}$ & $\mathrm{J} 7$ \\
\hline $\begin{array}{l}\text { Opportunity for a } \\
\text { promotion }\end{array}$ & $\begin{array}{l}\text { Opportunities for a quick } \\
\text { promotion }\end{array}$ & $\mathrm{O} 1$ \\
\hline \multirow[t]{4}{*}{ Salary/ benefits } & High-paying jobs & B1 \\
\hline & $\begin{array}{l}\text { Jobs that can improve personal } \\
\text { skills }\end{array}$ & $\mathrm{B} 2$ \\
\hline & $\begin{array}{l}\text { Jobs with the opportunity of } \\
\text { traveling outside the } \\
\text { region/abroad }\end{array}$ & B3 \\
\hline & High starting salary & B4 \\
\hline \multirow[t]{2}{*}{$\begin{array}{l}\text { Industry-Person } \\
\text { Congeniality }\end{array}$} & $\begin{array}{l}\text { Work that in line with the } \\
\text { educational background }\end{array}$ & $\mathrm{C} 1$ \\
\hline & $\begin{array}{l}\text { Jobs that are easily found in } \\
\text { various areas }\end{array}$ & $\mathrm{C} 2$ \\
\hline \multirow[t]{2}{*}{ Social status } & $\begin{array}{l}\text { A job that allows workers to } \\
\text { contribute to the natural } \\
\text { environment and social life }\end{array}$ & $\mathrm{S} 1$ \\
\hline & A job that is respected/fancy & $\mathrm{S} 2$ \\
\hline
\end{tabular}

The collected data was then processed and analyzed using Statistical Product and Service Solutions version 25 (SPSS v25). For testing the reliability and validity of the data, the Cronbach's Alpha parameter was used, with a test value above 0.7 , which indicates the right data consistency. The concept of Importance Performance Analysis (IPA) using Cartesian diagram, further namely perceptionimportance analysis, and descriptive statistics was carried out to identify students' perceptions and factors considered necessary in tourism industry careers. 
The cartesian diagram consists of four quadrants. Quadrant 1 ("keep up the good work") identifies an area where the average of importance and perception are above total average. Furthermore, Quadrant 2 ("concentrate here") identifies the job attributes that have more important score but need for improvements. Quadrant 3 ("low priority") identifies attributes that are less favorable and less important. Quadrant 4 ("possible overkill") identifies attributes that are favorable but less important for students. Meanwhile, descriptive analysis through crosstabulation was conducted to identify the characteristics of tourism students who crave a career in the tourism industry even after the Covid-19.

\section{Result and Discussion}

The collected data indicate that this study involved more female students $(61.6 \%)$ rather than male students. The majority of respondents in this study came from vocational institutions (73\%). Most of the res $\neg$ pondents have had an internship experience in the tourism industry (72\%). Only a few respondents had worked in the tourism industry before they attended higher education (32.7\%). Also, only a small part of respondents (36.5\%) stated that the tourism/hospitality study program was not their first choice on their enrolment.

Table 4

Characteristics of Sample

\begin{tabular}{lll}
\hline \multicolumn{1}{l}{ Respondent Characteristics } & $\boldsymbol{n}$ & $\mathbf{( \% )}$ \\
\hline $\begin{array}{l}\text { Gender } \\
\quad \text { Male }\end{array}$ & 162 & 38.4 \\
$\quad$ Female & 260 & 61.6 \\
$\begin{array}{l}\text { Current Education } \\
\quad \text { Diploma-3 }\end{array}$ & 163 & 38.6 \\
$\quad$ Diploma-4 & 145 & 34.4 \\
$\quad$ Bachelor's degree & 114 & 27.0 \\
$\begin{array}{l}\text { Previous Education } \\
\quad \text { Previously graduated from }\end{array}$ & 180 & 42.7 \\
$\quad$ Vocational High Schools in & & \\
$\quad$ Tourism & & \\
$\quad \begin{array}{l}\text { Previously graduated from non- } \\
\text { tourism High Schools }\end{array}$ & 242 & 57.3 \\
Had work experience in the tourism & & \\
industry before college/university & & \\
$\quad$ Yes & 138 & 32.7 \\
$\quad$ No & 284 & 67.3 \\
Had internship/practical work \\
experience
\end{tabular}

\section{Factors Considered Important}

The three factors that are considered as the most important in a job for undergraduate students were fun work environment (4.36), fun/enjoyable work (4.30), and friendly co-worker (4.27). The top three important factors are related to the nature of work. Meanwhile, three factors considered less necessary in a job than others were high-risk jobs (2.79), jobs with high starting-salaries (3.44), and respected/fancy jobs (3.54). These findings show that high-risk factor was not something to worry for the students in a job. Apart from that, respondents also considered that a high starting salary was not too necessary.

\section{Students' Perception}

In general, respondents' perceptions indicated that jobs in the tourism industry could not be able to satisfy their expectations. The attributes that the tourism industry may offer, according to respondents, were a fun/enjoyable work (4.11), a job that can improve personal skills (4.08), and a fun/enjoyable work environment (4.05). On the other hand, the attributes that got low perception which the tourism industry may not offer were a high-risk job (2.97), jobs with high starting salaries (3.38), and standard working hours (3.43).

Table 5

Variables and Indicators Applied

\begin{tabular}{|c|c|c|c|c|c|}
\hline \multirow[b]{2}{*}{ Codes } & \multicolumn{2}{|c|}{ Importance } & \multicolumn{2}{|c|}{ Perception } & \multirow[b]{2}{*}{$\begin{array}{c}\text { Gap } \\
\text { (Mp-Mi) }\end{array}$} \\
\hline & $\begin{array}{c}\text { Mean } \\
\text { (Mi) }\end{array}$ & SD & $\begin{array}{c}\text { Mean } \\
\text { (Mp) }\end{array}$ & SD & \\
\hline $\mathrm{J} 1$ & 4.30 & 1.16 & 4.11 & 1.12 & $(0.19)$ \\
\hline $\mathrm{J} 2$ & 4.36 & 1.18 & 4.05 & 1.11 & $(0.31)$ \\
\hline $\mathrm{J} 3$ & 4.27 & 1.20 & 3.95 & 1.10 & $(0.32)$ \\
\hline J4 & 3.71 & 1.09 & 3.43 & 1.15 & $(0.28)$ \\
\hline $\mathrm{J} 5$ & 3.69 & 1.08 & 3.49 & 1.07 & $(0.20)$ \\
\hline $\mathrm{J} 6$ & 3.94 & 1.10 & 3.76 & 1.08 & $(0.18)$ \\
\hline $\mathrm{J} 7$ & 2.79 & 1.10 & 2.97 & 1.08 & 0.18 \\
\hline $\mathrm{O} 1$ & 4.00 & 1.09 & 3.48 & 1.03 & $(0.52)$ \\
\hline B1 & 4.06 & 1.14 & 3.72 & 1.06 & $(0.34)$ \\
\hline B2 & 4.24 & 1.20 & 4.08 & 1.12 & $(0.16)$ \\
\hline B3 & 3.84 & 1.21 & 3.97 & 1.19 & 0.13 \\
\hline B4 & 3.44 & 0.99 & 3.38 & 0.95 & $(0.06)$ \\
\hline $\mathrm{C} 1$ & 3.75 & 1.13 & 3.76 & 1.13 & 0.01 \\
\hline $\mathrm{C} 2$ & 3.88 & 1.10 & 3.80 & 1.08 & (0.09) \\
\hline S1 & 4.11 & 1.21 & 4.01 & 1.13 & $(0.10)$ \\
\hline S2 & 3.54 & 1.03 & 3.58 & 1.00 & 0.04 \\
\hline Avg. & 3.87 & & 3.72 & & $(0.15)$ \\
\hline
\end{tabular}


The result showed that 12 attributes of job in tourism industry obtained negative perception compared to its importance. Therefore, the perception importance analysis used for identifying favorable and important attributes among the undergraduate students.

\section{Perception-Importance Analysis}

Based on perception-importance analysis (Figure 1), in the Quadrant-1, meaning to maintain good performance, consisted of seven attributes: fun work (J1), fun/enjoyable work environment (J2), friendly coworker (J3), jobs that allows freedom of work (J6), job that can improve personal skills (B2), jobs that are easily found in various areas (C2), and jobs that allows workers to contribute to the natural environment and social life (S1). Most of the tourism industry attributes that are considered essential and have good perceptions are jobs related to the nature of tourism industry work.

Meanwhile, two attributes considered essential but have low perceptions are covered in Quadrant-2: the opportunity for quick promotion (O1) and a job with a high salary (B1). Five attributes are included in Quadrant-3, meaning that they were considered not a priority and get low perception: standard working hours (J4), permanent work (J5), high-risk jobs (J7), jobs with high starting salaries (B4), and respected jobs (S2). However, jobs that allow traveling outside the region/abroad (B3) and jobs in line with the education (C1) are in Quadrant-4, which means that these attributes are less important even though they received good perceptions.

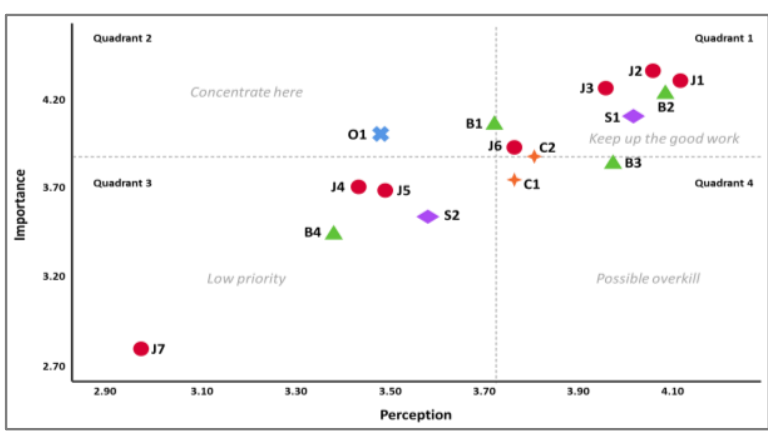

Figure 1. Perception-importance cartesian quadrant

Table 6

Perception-Importance Analysis Result

\begin{tabular}{cc}
\hline Quadrant & Code \\
\hline Quadrant 1 & $\mathrm{J} 1, \mathrm{~J} 2, \mathrm{~J} 3, \mathrm{~J} 6, \mathrm{C} 2, \mathrm{~B} 2, \mathrm{~S} 1$ \\
"keep up the good work" & $\mathrm{B} 1, \mathrm{O} 1$ \\
Quadrant 2 \\
"concentrate here" \\
Quadrant 3 \\
"low priority" \\
$\begin{array}{c}\text { Quadrant 4 } \\
\text { "possible overkill" }\end{array}$ & $\mathrm{J} 4, \mathrm{~J} 5, \mathrm{~J} 7, \mathrm{~S} 2, \mathrm{~B} 4$ \\
\hline
\end{tabular}

\section{The Desire to Pursue Career in the Tourism Industry}

As many as $90.5 \%$ of 422 respondents desired to pursue careers in the tourism industry before the COVID-19. However, the number decreased to $81.5 \%$ when the situation shifted to "after COVID-19." Similarly, uncertain respondents for tourism careers after COVID-19 increased by 9\%. Surprisingly, those who did not seem interested in the tourism industry before and after the COVID-19 remained the same.

Table 7

Students' Desire to Pursue a Tourism Industry Career Based on Their Socio-Demographic

\begin{tabular}{|c|c|c|c|}
\hline \multirow{2}{*}{ Characteristic } & \multicolumn{3}{|c|}{$\begin{array}{c}\text { Desire to have a career in } \\
\text { the tourism industry after } \\
\text { COVID-19 }\end{array}$} \\
\hline & Desire & $\begin{array}{l}\text { Doubt/ } \\
\text { Unsure }\end{array}$ & $\begin{array}{c}\text { Not } \\
\text { desire }\end{array}$ \\
\hline $\begin{array}{l}\text { Had an internship } \\
\text { experience in the } \\
\text { Government offices }\end{array}$ & $90 \%$ & $10 \%$ & - \\
\hline $\begin{array}{l}\text { Had an internship } \\
\text { experience in the non- } \\
\text { Government offices }\end{array}$ & $89 \%$ & $11 \%$ & - \\
\hline $\begin{array}{l}\text { Had work experience in } \\
\text { the tourism industry }\end{array}$ & $87 \%$ & $11 \%$ & $2 \%$ \\
\hline $\begin{array}{l}\text { Currently studying } \\
\text { Bachelor's degree }\end{array}$ & $87 \%$ & $13 \%$ & - \\
\hline $\begin{array}{l}\text { Tourism study program } \\
\text { was the first choice }\end{array}$ & $85 \%$ & $13 \%$ & $1 \%$ \\
\hline $\begin{array}{l}\text { Currently studying } \\
\text { vocational college for } \\
\text { Diploma-3 degree }\end{array}$ & $84 \%$ & $14 \%$ & $2 \%$ \\
\hline $\begin{array}{l}\text { Previously graduated } \\
\text { from vocational high } \\
\text { schools in } \\
\text { tourism/hospitality }\end{array}$ & $84 \%$ & $14 \%$ & $2 \%$ \\
\hline Female & $83 \%$ & $14 \%$ & $3 \%$ \\
\hline $\begin{array}{l}\text { Had an internship } \\
\text { experience in other } \\
\text { sectors }\end{array}$ & $83 \%$ & $10 \%$ & $7 \%$ \\
\hline $\begin{array}{l}\text { Previously graduated } \\
\text { from non-tourism high } \\
\text { schools }\end{array}$ & $80 \%$ & $17 \%$ & $3 \%$ \\
\hline Male & $80 \%$ & $18 \%$ & $2 \%$ \\
\hline $\begin{array}{l}\text { Had internship experience } \\
\text { in the tourism industry }\end{array}$ & $79 \%$ & $18 \%$ & $3 \%$ \\
\hline $\begin{array}{l}\text { Had no work experience } \\
\text { in the tourism industry }\end{array}$ & $79 \%$ & $18 \%$ & $3 \%$ \\
\hline $\begin{array}{l}\text { Tourism study } \\
\text { programme was not } \\
\text { the first choice }\end{array}$ & $75 \%$ & $20 \%$ & $5 \%$ \\
\hline $\begin{array}{l}\text { Currently studying } \\
\text { vocational college for } \\
\text { Diploma-4 degree }\end{array}$ & $74 \%$ & $20 \%$ & $6 \%$ \\
\hline
\end{tabular}


Based on socio-demographic characteristics, respondents who craved a career in the tourism industry (90\%) mostly have had an internship experience in the government sector. Interestingly, respondents who have had an internship in the practical tourism industry (79\%) tend to be less likely to continue sticking with it. Based on the education level, most of the students taking undergraduate programs $(87 \%)$ desired careers in the tourism industry rather than those studying Diploma-3 (84\%) and Diploma-4 (74\%). Respondents with the least desire in the tourism industry are those who are currently taking Diploma-4.

\section{Preferences for Careers in the Tourism Industry}

Based on cross-tabulation analysis, the sector of accommodation was the most engaging to respondents (51\%), followed by Meeting, Incentive, Convention, and Exhibition (MICE) (38\%) and food and beverages $(37.9 \%)$. Meanwhile, tour guides $(5.8 \%)$, marine tourism (5.5\%), and spas (2.3\%) are the business fields with the least interest. This finding is not too startling given that accommodation and food and beverage services, including the hotel and restaurant business, are the most popular fields and contribute significantly to absorbing labors in destinations. Based on education level, $80 \%$ of respondents from diploma programs chose the accommodation industry as the career field, whilst transportation services (48\%) and tourism consulting services (45\%) were favorited by respondents studying undergraduate programs (Bachelor's degree).

As Indonesia's most-visited destination by tourists, Bali attracted most respondents (47.7\%) compared to other locations. While, Labuan Bajo, designated as one of Indonesia's super-priority tourism destinations, was chosen by many respondents (29.7\%). Interestingly, few respondents chose Bandung $(0.6 \%)$ and Makassar $(0.6 \%)$. Although the two cities are known as the leading tourist destinations in Java and Sulawesi Islands, only a few respondents desired to pursue a career in those two cities.

Respondents also answered that they craved to have a career in the overseas industries. The European and Asian regions are their favorite destinations, showing that $24.7 \%$ of respondents wanted the European Region, followed by Japan (22.4\%), Dubai (21.2\%), and Singapore (14\%).
Table 8

Students' Preference of Business Lines in Tourism Industry

\begin{tabular}{|c|c|c|c|c|}
\hline \multirow{2}{*}{$\begin{array}{c}\text { Sectors within } \\
\text { Tourism Industry }\end{array}$} & \multicolumn{3}{|c|}{ Education Degree } & \multirow{2}{*}{$\begin{array}{c}\% \\
\text { Total } \\
\text { Resp. }\end{array}$} \\
\hline & $\begin{array}{l}\text { Dip. } \\
3\end{array}$ & $\begin{array}{l}\text { Dip. } \\
4\end{array}$ & Bachelor & \\
\hline Accommodation & $45 \%$ & $36 \%$ & $19 \%$ & $51 \%$ \\
\hline MICE & $42 \%$ & $34 \%$ & $24 \%$ & $38 \%$ \\
\hline $\begin{array}{l}\text { Food and } \\
\text { beverages }\end{array}$ & $48 \%$ & $30 \%$ & $22 \%$ & \\
\hline $\begin{array}{l}\text { Tourism } \\
\text { Developer }\end{array}$ & $35 \%$ & $27 \%$ & $38 \%$ & $30 \%$ \\
\hline Travel agent & $28 \%$ & $36 \%$ & $36 \%$ & $25 \%$ \\
\hline $\begin{array}{l}\text { Tourism } \\
\text { consulting } \\
\text { services }\end{array}$ & $16 \%$ & $39 \%$ & $45 \%$ & $21 \%$ \\
\hline $\begin{array}{l}\text { Tourism } \\
\quad \text { transportation }\end{array}$ & $35 \%$ & $17 \%$ & $48 \%$ & $21 \%$ \\
\hline $\begin{array}{l}\text { Recreation and } \\
\text { entertainment }\end{array}$ & $42 \%$ & $34 \%$ & $24 \%$ & $17 \%$ \\
\hline Tourist attraction & $21 \%$ & $37 \%$ & $42 \%$ & $16 \%$ \\
\hline $\begin{array}{l}\text { Tourism } \\
\quad \text { information } \\
\text { services }\end{array}$ & $41 \%$ & $23 \%$ & $36 \%$ & $6 \%$ \\
\hline Tourist guide & $45 \%$ & $25 \%$ & $30 \%$ & $5 \%$ \\
\hline Marine tourism & $37 \%$ & $42 \%$ & $21 \%$ & $5 \%$ \\
\hline Spas & $50 \%$ & $37 \%$ & $13 \%$ & $2 \%$ \\
\hline
\end{tabular}

Table 9

Students' Preference of Destinations to Work in Tourism Industry

\begin{tabular}{lc}
\hline \multicolumn{1}{c}{ Destinations } & $\begin{array}{c}\text { \% Total } \\
\text { Resp. }\end{array}$ \\
\hline Bali & $47.7 \%$ \\
Labuan Bajo & $29.7 \%$ \\
European region & $24.7 \%$ \\
Japan & $22.4 \%$ \\
Dubai & $21.2 \%$ \\
Raja Ampat & $20.9 \%$ \\
Borobudur area & $18 \%$ \\
Lombok-Mandalika & $18 \%$ \\
Singapore & $14 \%$ \\
United States & $11.6 \%$ \\
Bromo-Tengger-Semeru area & $9.9 \%$ \\
Toba area & $8.1 \%$ \\
Wakatobi & $7.6 \%$ \\
Bangka-Belitung & $5.2 \%$ \\
Hongkong & $3.8 \%$ \\
Malaysia & $3.5 \%$ \\
Jakarta & $2.9 \%$ \\
South Korea & $1.5 \%$ \\
Thailand & $0.9 \%$ \\
Bandung & $0.6 \%$ \\
Makassar & $0.6 \%$ \\
Others & $5.2 \%$ \\
\hline
\end{tabular}




\section{Discussion}

Some of the findings of this study are consistent with several previous studies. The students considered nature of work, especially fun atmosphere as the most important factor for them in a workplace. According to Chan (2019), workplace fun is necessary because it can give workers a sense of comfort and flexibility. With something comforting, workers could feel connected to the company, and their daily work and strong social ties can be built so that it has a positive effect on service for tourists/guests. This finding is also consistent with the findings of Richardson and Butler (2012), where fun work was an essential attribute for students in Malaysia. The students reckoned that tourism industry might offer a fun workplace.

However, the evidences show that undergraduate students of tourism and hospitality program consider salary and social status less important in a job. This finding is different from the findings in Malaysia and Australia, which concluded that a high starting salary and social status was an important attribute (Richardson, 2009; Richardson \& Butler, 2012; Ibrahim et al., 2020). Besides, the low starting salary and social status offered by the majority of the tourism industry was one of the main factors causing students not to choose a career in the tourism industry (Lu \& Adler, 2009; Tan et al., 2016).

On the other hand, amid the Covid-19 pandemic, the students less concerned with a high-risk job they might face once graduated. Working as a tourism labor is considered safe. Therefore, they supposed that a job with a high-risks is not something to be feared.

The evidence which suggested Bali as the most preferred destination to work is predictable. The land of Gods is a globally well-known tourist destination where numerous tourism business bloom. The privileges they might attain when working in Bali are chances to work in reputable industry and the same time, they are able to make a holiday in several tourist destinations in Bali. Those advantages are related to stu-dents' positive perception in tourism industry about a job that allow traveling.

However, this study also discovered that undergraduate students of tourism and hospitality in Indonesia aspire to work abroad. As prospective tourism worker who earned higher education in a developing country, working abroad with a higher salary offer than their home country is prestigious and beneficial as well. Working in a foreign country, particularly in an advanced economy, is the answer to domestic tourism industry's low salary.

\section{Conclusion and Implication}

The present study succeeded in finding the perceptions, attitudes, and preferences of tourism and hospitality students for tourism industry careers. In general, the majority of tourism and hospitality students in Indonesia still craved to have a career in tourism industry even in amid and post Covid-19 pandemic. Although some students were hesitant, the number was insignificant. However, students appreciated fun at work and considered it as the most important factor in a job. Concurrently, they believed the tourism industry capable to provide workplace fun.

This present study provides practical implication for the government and tourism businessperson as well. As for the government, preparing the best talents for work is beneficial to strengthen the competitiveness of Indonesia's future tourism. Since workers play an influential role in the tourism industry's sustainability, preparing and preserving competent labors who earned higher education is an essential agenda. Moreover, the government is necessitated to develop and improve tourism educational institutions in Indonesia, such as vocational schools and higher education, in preparing skilled, educated, and passionate future talents to serve domestic tourism industry.

Meanwhile, employers and business player must continue maintaining a pleasant work environment and improving workers' skills to attract excellent talents who earned higher education in tourism. Besides, business actors also need to open opportunities for workers to be creative and innovative at work so that workers can contribute to their environment and social life. However, speaking about the challenges, tourism business players need to increase the offered salary and provide opportunities for promising promotions so as to attract workers from tourism-related institutions. If domestic business players cannot answer these two important attributes, the possibility of domestic talents to speculate a career abroad is inevitably wide open.

Although this study managed in finding evidences in several cities in Indonesia, this study merely examined five variables used by Kusluvan and Kusluvan (2000). Consequently, this study will not be as intense as other studies that were comprehensively explaining attitudes, perceptions, and the desires of students who craved to have careers in the tourism industry. Future research should also explore the other va-riables and apply an advanced quantitative analysis to obtain a more comprehensive finding. 


\section{References}

Adhoch, R. (2019). Perceived benefits and making a career choice in the hospitality industry: Is it worth it? ASEAN Journal on Hospitality and Tourism, 5(3), 1-11. https://doi.org/10.20431/24 55-0043.0503003.

Ahmad, R., Rashid, B., \& Shariff, N. M. (2014). Malaysian hospitality industry: Graduates' justifycation for leaving the industry. International Journal of Management Studies, 21(2), 1-20.

AlBattat, A. R. S., \& Som, A. P. M. (2013). Employee dissatisfaction and turnover crises in the Malaysian Hospitality Industry. International Journal of Business and Management, 8(5), 62-71. https ://doi.org/10.5539/ijbm.v8n5p62.

AlBattat, A. R., Som, A. P. M., \& Helalat, A. S. (2014). Higher dissatisfaction higher turnover in the hospitality industry. International Journal of Academic Research in Business and Social Sciences, 4(2), 45-52. https://doi.org/10.6007/ijarbss/v4-i2 1591.

Amissah, E. F., Mensah, A. O., Mensah, I., \& Gamor, E. (2020). Students' perceptions of careers in Ghana's hospitality and tourism industry. Journal of Hospitality and Tourism Education, 32(1), 113. https://doi.org/10.1080/10963758.2019.1654 884.

Anandhwanlert, T., \& Wattanasan, C. (2017). Career perception of undergraduate students on tourism and hospitality industry in Thailand. Global Advanced Research Journal of Management and Business Studies, 5(10), 339-346.

Bachrun, K. (2020). Data tenaga kerja pariwisata 2018-2019. Presented by Central Statistics Agency on October, 2020.

Bamford, K. L. (2012). Undergraduate student perceptions of a career in the tourism and hospitality industry in New Zealand. Published dissertation. University of Otago. Retrieved from: https://ourarchive.otago.ac.nz/bitstream/handle/ 10523/2448/bamfordkirstenl2012mtour.pdf?seq uence $=1$.

Baum, T. (2016). Human resource issues in international tourism. 1st Ed. Oxford, UK: Butter-worthHeinemann.

Brien, A. (2004). Do I want a job in hospitality? Only till I get a real job. In Proceedings of the New Zealand tourism and hospitality research conference (pp. 35-42). Wellington, New Zealand: Victoria University of Wellington.

Brown, D. (2002). Career choice and development. (4th ed.). New Jersey, NJ: John Wiley \& Sons.
Budi, S. P. (2015). Model struktural pengembangan da-ya saing destinasi wisata studi kasus kota Jakarta. University Research Colloquium, 134 142.

Cassel, S. H., Thulemark, M., \& Duncan, T. (2018). Career paths and mobility in the Swedish hospitality sector. Tourism Geographies, 20(1), 29-48. https://doi.org/10.1080/14616688.2017.1 402946

Chan, M. C. (2017). Exploring how hospitality undergraduate students' perceptions and attitudes towards a career in the hospitality industry are affected by their work experience: A New Zealand quantitative study. Retrieved from: https:// openrepository.aut.ac.nz/bitstream/handle/ 10292 /10421/ChanMC.pdf?sequence=3\&isAllowed= $\mathrm{y}$

Chan, S. C. H. (2019). The antecedents of workplace fun in the hospitality industry: A qualitative study. Journal of Human Resources in Hospitality and Tourism, 18(4), 425-440. https://doi.org/10. 108015332845.2019 .1626794

Dewar, K., Sayers, J., \& Meyer, D. (2002). Hopes, dreams and reality. Journal of Teaching in Travel \& Tourism, 2(1), 81-97. https://doi.org/10.1300/ J172v02n01_01

Dinarto, D., Wanto, A., \& Sebastian, L. C. (2020). Global health security-COVID-19: Impact on Bintan's tourism sector. RSIS Commentaries, 033-20, retrieved from: https://dr.ntu.edu.sg/ handle/10356/137356

El-Dief, M., \& El-Dief, G. (2019). Factors affecting undergraduates' commitment to career choice in the hospitality sector: Evidence from Saudi Arabia. Journal of Human Resources in Hospitality and Tourism, 18(1), 93-121. https://doi.org/10. $1080 / 15332845.2019 .1526533$

Hakim, L. (2020). COVID-19 and the moment to evaluate tourism euphoria, Indonesia. Journal of Indonesian Tourism and Development Studies, 8 (2), 119-123. https://doi.org/10.21776/ub.jitode 2020.008.02.09

Ibrahim, M. Z. F., Saber, J. M., Mustapha, R. I. P. R., Othman, N., \& Salim, A. (2020). Factor affecting university undergraduate students' perception's toward career enhancement in hospitality industry: A case of UiTM Penang. Journal of Social Sciences and Humanities, 4, 19-26.

Jiang, B., \& Tribe, J. (2009). Tourism jobs - short lived professions: Student attitudes towards tourism careers in China. Journal of Hospitality, Leisure, Sport and Tourism Education, 8(1), 4-19. https: //doi.org/10.3794/johlste.81.168 
Kusluvan, S., \& Kusluvan, Z. (2000). Perceptions and attitudes of undergraduate tourism students towards working in the tourism industry in Turkey. Tourism Management, 21(3), 251-269. https:// doi.org/10.1016/S0261-5177(99)00057-6.

Lacher, R. G., \& Oh, C. O. (2012). Is tourism a lowincome industry? Evidence from three coastal regions. Journal of Travel Research, 51(4), 464 472. https://doi.org/10.1177/0047287511426342

Le, A. H., Klieve, H., \& McDonald, C. V. (2018). Tertiary students' perceptions of hospitality careers in Vietnam. Empirical Research in Vocational Education and Training, 10(14). https://doi.org/10. 1186/s40461-018-0075-6.

Lee, P. C., Lee, M. J., \& Dopson, L. R. (2019). Who influences college students' career choices? an empirical study of hospitality management students. Journal of Hospitality and Tourism Education, 31(2), 74-86. https://doi.org/10.1080/109 63758.2018 .1485497

Liu, A., \& Wall, G. (2006). Planning tourism employment: A developing country perspective. Tourism Management, 27(1), 159-170.

Lu, T. Y., \& Adler, H. (2009). Career goals and expectations of hospitality and tourism students in China. Journal of Teaching in Travel and Tourism, 9(1-2), 63-80. https://doi.org/10.1080/ 15313220903041972.

Mohammed, A. A. M. (2018). Students' intention to join the hotel industry in Malaysia: The role of physical working conditions, pay and benefits, and promotion opportunities. Journal of Business and Retail Management Research, 12(4), 240-245. https://doi.org/10.24052/jbrmr/v12is04/art-24.

Pitso, A. R. M. (2018). Assessing the effects of inadequate human capital affecting brand image of the hospitality and tourism industry, published doctoral dissertation from https://openscholar.dut.ac. za/bitstream/10321/3294/1/PITSOARM_2018.p df, Durban University of Technology.

Richardson, S. (2009). Undergraduates' perceptions of tourism and hospitality as a career choice. International Journal of Hospitality Management, 28(3), 382-388. https://doi.org/10.1016/j.j.jhm.2 008.10 .006$.

Richardson, S., \& Butler, G. (2012). Attitudes of Malaysian tourism and hospitality students towards a career in the industry. Asia Pacific Journal of Tourism Research, 17(3), 262-276. https://doi.or g/10.1080/10941665.2011.625430.

Sibanyoni, J. J., Kleynhans, I. C., \& Vibetti. (2015). South African hospitality graduates' perceptions of employment in the hospitality industry.
African Journal of Hospitality, Tourism and Leisure, 4(1), 1-16. http://www.ajhtl.com/ uploads/7/1/6/3/7163688/article_12_vol_4_1_2 015_final.pdf.

Škare, M., Soriano, D. R., \& Porada-Rochoń, M. (2020). Impact of COVID-19 on the travel and tourism industry. Technological Forecasting and Social Change, 163, 120469. https://doi.org/10. 1016/j.techfore.2020.120469.

Solnet, D., \& Hood, A. (2008). Generation Y as hospitality employees: Framing a research agenda. Journal of Hospitality and Tourism Management, 15(1), 59-68. https://doi.org/10.1375/jhtm. 15.59 .

Tan, Z. M. A., Baharun, N., Wazir, N. M., Ngelambong, A. A., Ali, N. M., Ghazali, N., \& Tarmazi, S. A. A. (2016). Graduates' perception on the factors affecting commitment to pursue career in the hospitality industry. Procedia-Social and Behavioral Sciences, 224(16), 416-420.

Tuzunkan, D. (2018). Undergraduate tourism students' perceptions and attitudes towards tourism industry: The case of Daejeon, South Korea. Geojournal of Tourism and Geosites, 21(1), 103-111.

UNWTO. (2020). Impact assessment of the COVID19 outbreak on international tourism. Retrieved from https://www.unwto.org/impact-assessmentof-the-covid-19-outbreak-on-internationaltouris $\mathrm{m}$.

Vu, H. T. (2020). Factors affecting the career choice of students in tourism: Evidence from Danang city, Vietnam. Management Science Letters, 10(13), 3183-3188. https://doi.org/10.5267/j.msl.2020.5. 003.

Wan Yim King, P., \& Kong Weng Hang, F. (2011). Career perceptions of undergraduate gaming management students. Journal of Teaching in Travel and Tourism, 11(4), 367-391. https://doi.org/10. 1080/15313220.2011.624409.

Wang, S., \& Huang, X. (2014). College students' perceptions of tourism careers in China: Implications for the industry and education providers. Journal of Human Resources in Hospitality and Tourism, 13(3), 211-233. https://doi.org/10.108 0/1533284 5.2014.866449.

Wen, H., Li, X., \& Kwon, J. (2019). Undergraduate students' attitudes toward and perceptions of hospitality careers in mainland China. Journal of Hospitality and Tourism Education, 31(3), 159172. https://doi.org/10.1080/10963758.2018.148 7787. 
White, P. (2007). Education and career choice: A new model of decision making. UK: Palgrave Macmillan. https://doi.org/10.1057/9780230624849.
Wijesundara, W. G. S. R. (2015). An Evaluation of graduates' perception on employment in tourism and hospitality industry. Tourism, Leisure and Global Change, 2, 172-182. 